Külgazdaság, LXIV. évf., 2020. szeptember-október (90-104. o.)

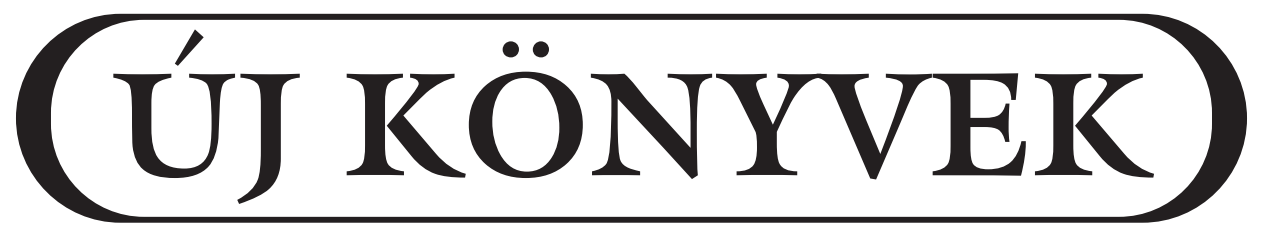

\title{
A gazdaságpolitika újragondolása és a válság Stephanie Kelton: The Deficit Myth: Modern Monetary Theory and the Birth of the People's Economy
}

Public Affairs, 2020, New York, 304 oldal

A válság nyomán világszerte felerősödött az igény a gazdaságpolitika kereteinek és a makroökonómiának az újragondolására. A modern monetáris elmélet által képviselt nézetek kerültek elötérbe. E szerint a pénzt az állam teremti, de alapvetöen fontos, hogy a monetáris rendszer operatív elemeit és a pénzügyi környezet részleteit ismerje az, aki ebbe beavatkozik. A költségvetésnek technikai finanszirozási korlátja nincs, de a reálgazdasági, az inflációs és az ökológiai korlátokat tiszteletben kell tartani. E korlátok egységes mérlegelésében segít a Godley-típusú makroökonómiai elszámolási rendszer, a stock-flow-konzisztens megközelités. A kiélezett vitába robbant be Stephanie Kelton könyve, amely a modern monetáris elmélet fiskális összefüggéseit mutatja be közérthetöen.

Journal of Economic Literature (JEL) kódok: E12, E52, E62.

Kulcsszavak: modern monetáris elmélet, fiskális politika, pénzteremtés.

Abstract

The Crisis Calls for Rethinking Economic Policy Some thoughts inspired by Stephanie Kelton's book The Deficit Myth: Modern

Monetary Theory and the Birth of the People's Economy

Public Affairs, 2020, New York

ISTVÁN ÁBEL

The global scale of the COVID-19 pandemic renders traditional tools of macroeconomics illsuited for handling the crisis. A growing consensus unfolded that it is time to rethink economic policy. There is a need for prompt and large fiscal and monetary intervention. The heterodox 
A gazdaságpolitika újragondolása és a válság

economics represented by modern monetary theory (MMT) offers a novel approach to assess and meet these needs. MMT calls for countries that can print their own currency to ignore debt-toGDP ratios, rely on the central bank to backstop public debt, and continue to run deficit spending unless and until unemployment and inflation return to normal. Proper use of this approach requires a clear understanding of the functioning of the monetary and banking system. Godleytype stock-flow consistent macroeconomic accounting helps to navigate with these and other real economic and ecological constraints. Stephanie Kelton's book The Deficit Myth does a good job by discussing these important topics from a new perspective, in a manner that was simultaneously shocking and yet compelling.

Journal of Economic Literature (JEL) codes: E12, E52, E62.

Keywords: modern monetary theory, fiscal policy, money creation.

Stephanie Keltonnak (2020a) a költségvetési deficitet újraértelmező könyve világsiker lett. Sokan fejtették ki véleményüket a könyvéről. A nagy visszhangban szerte a világon egyaránt keveredik pozitív és elítélő vélemény is.

Ebben az írásban azt kísérlem meg, hogy a makroökonómiának a válság nyomán kibontakozó újraértékelésére, megújitására született törekvések keretébe illesztve ismertessem Kelton (2020a, 2020b) főbb megállapításait. E megközelítést azért tartom fontosnak, mert ez képes megvilágítani a lelkes egyetértő és az élesen kritikus vélemények tartalmát és indokait. Az elismerő dicséretekben és a lesújtó kritikai véleményekben egyaránt a jelenlegi válság okozta kihívások kényszere és a megoldásokért érzett felelősség tükröződik. Azt remélem, hogy mindkét oldal mégoly eltérő véleményét is termékeny hozzájárulásként hasznosíthatjuk, ha azt a háttérben meghúzódó elméleti keretbe illesztve értékeljük. A mítoszok, hibás értelmezések és a paradoxonok kiélezése a viták természetes velejárója, de ez az ellentétek túlhangsúlyozására csábítja mindkét oldalt, ami félreértéshez és egyoldalú megközelítéshez vezet. Ezt igyekszem elkerülni ebben az írásban. Elöre kell azt is bocsátanom, hogy a vitának keretet adó elmélet, a modern monetáris elmélet (Modern Monetary Theory, röviden MMT) propagálójának vallom magam, de úgy vélem, hogy ez az elmélet csak akkor tud hasznosan hozzájárulni a válság kezeléséhez, ha higgadtan igyekszünk kerülni a sajtóvéleményekben és az elméleti csatározásokban használt zajos, de gyakran félreértésekhez vezető érvelést. 


\section{A makroökonómia és a gazdaságpolitika}

A The Economist 2020. július 25-i száma (2020) hosszú írást szentelt a makroökonómiában végbemenő megújulásnak. ${ }^{1}$ Érdemes ez alapján röviden érinteni ezt a tudományos trendet, ami segít megértenünk azt is, hogy az MMT térnyerésének miért éppen ma vagyunk tanúi, holott annak számos markáns eleme már a múlt század elején megjelent. ${ }^{2}$ A makroökonómia létrejötte Keynes (1965) foglalkoztatásról, kamatról és a pénz általános elméletéről szóló mủvével kezdődött. Keynes tanításának nagy hatása volt az 1940-es évektől a gazdaságpolitika alakítására. A háború utáni helyreállítás és az azt követő fellendülés állami segítséggel, a gazdasági ciklus alakításába történő aktív beavatkozás útján valósult meg. Ehhez hatékony elméleti keretül szolgált a munkahelyteremtésre, a teljes foglalkoztatás útjában álló akadályok kezelésére irányuló keynesi elvek alkalmazása. Keynes az 1929-1933. évi nagy gazdasági válság példáján megmutatta, hogy a gazdaságban a klasszikus közgazdaságtan által korábban feltárt és középpontba állított önkorrekciós mechanizmusok nem elegendőek. A klasszikus tanítás szerint a kamat rugalmas alakulása biztosítja a megtakarítások és a beruházások egyensúlyát. ${ }^{3}$ Keynes erről röviden azt tartotta fontosnak, hogy ez az egyensúly bármilyen kamatszinten létrejön, de ôt magát csak az az egyensúly érdekli, amely a teljes foglalkoztatást biztosítja. A gazdaságban ez az egyensúly csak állami beavatkozás útján biztosítható, mert az önkorrekciós mechanizmusok recesszióhoz vezethetnek. Ezek elkerülésére költségvetési kiadások vállalására van szükség annak érdekében, hogy a visszaesés során kieső keresletet pótolják. Azt remélve, hogy a növekedés beindulásával, a fellendüléssel majd csökkenteni lehet a recesszió idején felhalmozott adósságot. A gazdaságpolitikát ekkor a fiskális eszközök széles körü alkalmazása jellemezte.

Az 1970-es években bekövetkezett recesszió idején azonban ez a gyakorlat kudarcot vallott. A kiadások növelése az inflációt fokozta, a munkanélküliség pedig magas szinten maradt, mivel a gazdaság stagnált (stagfláció). Erre a problémára a keynesi recept nem tudott megoldást adni, de a klasszikus tanításhoz való visszatérés sem, mivel ez is azt feltételezte, hogy a munkanélküliség és az infláció között ne-

\footnotetext{
1 The covid-19 pandemic is forcing a rethink in macroeconomics, Jul 25th 2020: https://www. economist.com/briefing/2020/07/25/the-covid-19-pandemic-is-forcing-a-rethink-in-macroeconomics

${ }^{2}$ Érdekes egybeesés a mai helyzettel, hogy az I. világháború utáni spanyolnátha-világjárvány hatásaival és következményeivel párhuzamba hozható az az elméleti megújulási igény, ami teret engedett ennek a változásnak egy olyan tudományos közegben, amelyet a közgazdaságtanban a klasszikus iskolák uraltak.

${ }^{3}$ A hagyományos felfogást uraló kamatelméletek kritikáját mutattuk be az Ábel \& Lehmann (2019) és Ábel et al. (2018) írásokban.
} 
gatív korreláció van, mert a munkanélküliség növekedése a keresletet is visszafogja. Milton Friedman monetarizmusa új megközelítést javasolt, amelyet az 1980-as évek során a Paul Volcker vezette Fed sikerrel alkalmazott. A módszer egyszerủ volt, a pénzmennyiség korlátozása az infláció letörésére bevált. Az infláció, amely 14,8 százalékos volt 1980 márciusában, 1983-ra 3 százalék alá esett. A kamatot emelték, 1981 júniusában már 20 százalék volt a mértéke. Igaz, hogy ez mély recesszióhoz és 10 százalékot meghaladó munkanélküliséghez vezetett. Emiatt rövid életủ volt ez a kísérlet. A friedmani monetáris politika alkalmazása a gyakorlatban megbukott, de az elméletet hosszú ideig uralta. Az elmélet kitartása e megközelítés mellett azzal menthető, hogy a gyakorlati kudarc nem volt meglepö. Előre tudták e politika alkalmazásának következményeit, de vállalták, mert azt vallották, hogy az alacsony és stabil árak biztosítása fontosabb a gazdaság hatékony müködtetéséhez, mint a munkanélküliség növekedésének megelőzése. Azt vallották, hogy fel kell hagyni a jövedelmi egyenlőtlenségek mérséklésére alkalmazott és gyakran a rövid távú hatékonyságot rontó állami beavatkozással. A friedmani kísérlet bukása ellenére a monetáris politikában ezután is hosszú ideig ebben az elméleti keretben gondolkodtak. A gazdaságpolitikát a fiskális eszközök kordában tartása érdekében egyre inkább a monetáris eszközök határozták meg. Az 1990-es években a keynesi elvek némelyikét beemelve kialakult egy új konszenzus. A gazdaságpolitikát a neoklasszikus iskola alapjaira építve továbbra is a stabilan alacsony infláció elérése végett alkalmazták, de már lehetőség nyílt ezekben a recessziós időszakokban a munkanélküliség mérséklése érdekében hozott intézkedésekre is. A monetáris politikában felhagytak a pénzmennyiség szabályozásával, helyette a rövid távú kamatok alakítására összpontosult a figyelem (Ábel, 2019). A globális pénzügyi válságra a monetáris politika a kamatok gyors csökkentésével reagált. A jegybanki alapkamat hamar a nulla szint közelébe került, ami egyfajta korlátot jelent. A továbbra is szükségesnek ítélt lazítás biztosítása érdekében a mennyiségi lazítás eszközeihez folyamodtak a jegybankok (Fiebiger \& Lavoie, 2020). A 2007-2008. évi globális pénzügyi válságot hosszú stagnálás és lassú fellendülés követte. A gazdaságpolitika hagyományos monetáris politikai eszközei nem voltak hatásosak a recesszióból való kilábalás gyorsítására, és egyre inkább nyilvánvalóvá vált, hogy ebben a helyzetben a költségvetés eszközeire kellene támaszkodni. A Covid-19 vírusválság következményei nyomán ez a nézet gyorsan előtérbe került, és széles körben elfogadták. Egy paradigmaváltás tanúi lehetünk ismét, de most nem arról van szó, hogy a monetáris politikával szemben ismét a keynesi fiskális szempontok kerülnének előtérbe, hanem inkább arról, hogy egy új pénzelmélet keretében a monetáris és a fiskális szempontok egyaránt fon- 
tos szerepet játszanak. Leegyszerüsítve, a monetáris politika a kamatok alacsonyan tartásán őrködik, és ezzel szolgálja a fiskális intézkedések érvényesülését. Ez nagy különbség a 2000-es években elterjedt gyakorlattal szemben, amikor a monetáris politika a kamatok emelésével igyekezett nehezíteni a költségvetés finanszírozását és visszafogni a kormányzatok túlköltési hajlamából fakadó deficitet. A fiskális politika korlátok közé szorítva nem volt képes érdemben támogatni a recesszióból való kilábalást. A monetáris politika ugyanakkor önmagában nem volt eléggé sikeres a konjunktúra élénkítésében, ebben a fiskális politikára kellett volna támaszkodni. Jelenleg a fiskális expanziót az infláció tartósan alacsony szintje lehetővé teszi. Ebbe a helyzetbe robbant be Stephanie Kelton könyve, amely ilyen körülmények között egyenesen kívánatosnak állítja be a deficitet.

\section{A költségvetési deficit mítosza}

Érdekes ismertetést közöl Kelton könyvéröl Pogátsa (2020), kiemelve, hogy a könyv a modern monetáris elmélet (MMT) alapgondolatait mutatja be. Ebben az írásban én is ebből indulok ki, és azt értékelem, hogy a modern monetáris elmélet mivel járulhat hozzá a makroökonómia megújításához. Kelton könyve nagy siker lett, amihez a téma aktualitása mellett az is hozzájárul, hogy egy jól felépített polemikus írás, amely több paradoxon formájában, a szerző által mítosznak nevezett, általánosan elfogadott állítást cáfolva ütközteti nézeteit a hagyományos elmélet alapelveivel, megállapításaival. A vita izgalmas, ugyanakkor némileg egyoldalú értelmezést sugall, ami szinte provokálja az olvasót kifogások és ellenvélemények megfogalmazására. A téma iránt felkeltett nagy figyelmet jelzi, hogy a könyvröl számos ismertetés jelent meg folyóiratokban, de nagy hírủ napilapok, így a Financial Times, ${ }^{4}$ a New York Times, ${ }^{5}$ a Wall Street Journal ${ }^{6}$ és más rangos médiumok is foglalkoztak vele.

${ }^{4}$ Financial Times: Jackson (2020).

${ }^{5}$ New York Times: Kelton (2020b).

${ }^{6}$ Wall Street Journal: Cochrane (2020). 
A gazdaságpolitika újragondolása és a válság

Hat fejezetben hat mítosz lerombolása

a) A költségvetési deficitnek nincsen finanszírozási korlátja

Kelton könyvének első fejezete azt a nézetet támadja, hogy a költségvetési korlát a kormányokra éppen úgy vonatkozik, mint a magánszektorra, a háztartásokra vagy a vállalatokra. Míg szerinte az utóbbiak csak azt tudják elkölteni, ami a számlájukon van, addig a költségvetés megteheti, hogy elöször költ, és csak utána szed adót (Kelton, 2020a:24). Sőt, elvileg mindig ez történik, mivel a költségvetési kiadás (hiány) hozza forgalomba a pénzt. Éppen az adófizetés kényszere kölcsönöz értéket a pénznek. Az állam által forgalomba hozott papírpénz (önmagában értéket nem jelentő fedezet nélküli pénz - fiat money) éppen attól válik vonzóvá a magánszektor számára, hogy ebben kénytelen adót fizetni. Mivel mindenki fizet adót, így ez az eszköz általánosan elfogadottá válik. Tehát mítosz, hogy az államra ugyanolyan költségvetési korlát vonatkozna, mint a háztartásra, hogy előbb kell megszereznie azt, amit elkölt. Az állam nyomtathat pénzt, a háztartás nem.

Ez az állítás meggyőző, de nagyon leegyszerüsítő, emiatt sokan Kelton könyvének már az indító állításával kapcsolatban is kifogásokat fogalmaznak meg. Sőt, Kelton még azt is hangsúlyozza, hogy a költségvetés előbb költ, ezzel hozza forgalomba a pénzt, és csak utána adóztat, ami a pénz megszünését jelenti, a korábban teremtett pénzt így vonja ki a forgalomból. Eleve megtévesztő, hogy ez a megfogalmazás azt sugallja: a költségvetés anélkül költhet, hogy a számláján pénz lenne. Ez természetesen nem igaz, a költségvetés is csak azt tudja átutalni, ami a számláján van. Az igaz, hogy a költségvetés képes pénzt teremteni, így képes növelni ezen keresztül a számláján levő egyenleget anélkül, hogy előbb az adókat kellene beszednie. A pénzteremtés folyamata azonban a gazdaság intézményi jellemzőit tükrözi, és szigorúan szabályozott számviteli elöírások keretében történik, ami természetesen a költségvetésre nézve is érvényes. Amíg a mai intézményi jellemzők és szabályok érvényesek, addig ez sok szempontból korlátot jelenthet.

A modern monetáris elmélet a pénzteremtéssel kapcsolatban az endogén pénzelméletre épül. Erről részletes képet ad Ábel et al. (2016) írása. Talán meglepő, de az endogén pénzelmélet nem azt hangsúlyozza, hogy a pénzt az állam teremti. Elfogadja, hogy a hagyományos elméletben a hangsúly ezen az állami pénzteremtésen van, de bemutatja, hogy ezen az úton az ún. külső pénz jön létre. Mennyiségének változását a költségvetési hiány alapvetően korlátozza. A gazdaság szempontjából ennél fontosabb szerepet játszik az ún. belső pénz, amely a bankok hitelnyújtásá- 
val kerül forgalomba és a hitelek visszafizetésével szünik meg. Ezt nevezik számlapénznek. Az endogén pénzteremtés esetében két fontos elemet ki kell emelni. Az egyik az, hogy a bank csak saját ügyfelének nyújt hitelt, amit a nála vezetett folyószámlán ír jóvá. Ennek egyenes következménye, hogy a banknak nincsen szüksége ehhez elözőleg betétet gyüjteni, mert a hitelt finanszírozó betét ezzel a jóváírással keletkezik. A másik fontos jellemző az, hogy az endogén pénzelmélet elveti a bankokat pénzközvetítő szerepben értelmező megközelítéseket, aminek messzemenő következményei vannak a monetáris politika elméleti kereteire nézve. A hitelfelvevő továbbutalhatja az így szerzett pénzt, de ez a pénz valamely más bankhoz kerül, vagyis a bankrendszer szintjén ez nem szünik meg. A pénz a hitel visszafizetésével szünik meg. A pénzforgalom szempontjából nincsen különbség, hogy a zsebünkben vagy a számlánkon lévő pénz melyik úton került forgalomba, tehát ilyen értelemben nincsen különbség a külső és a belső pénz között. A modern gazdaságban azonban a pénz 95 százaléka belső pénz, melynek mennyiségét a piac a konjunktúra alakulásától függően alakítja. Akkor van baj, ha a konjunktúra olyan irányt vesz, hogy a magánszektor tömegesen kénytelen az adósságát leépíteni, a hiteleit visszafizetni. Ekkor a pénzmennyiség gyorsan zsugorodhat, lavinaszerűen rontva a konjunkturális kilátásokat. Ezt tapasztaltuk a 2007-2008. évi globális pénzügyi válság idején, és félö, hogy most is hasonló vagy rosszabb következhet be a koronavírus-járvány által kiváltott válság nyomán. A konjunktúra élénkítésére a keynesi recept, a költségvetési beavatkozás a kézenfekvő. A baj ezzel az, hogy a költségvetési szabályok és a müködési rend meglehetősen szigorú korlátokat érvényesít, így reménytelennek látszik, hogy a forgalomban hozzávetőleg 5 százalékos súlyt képviselő külső pénz olyan gyorsan tudjon bővülni, hogy a 95 százalékos súlyú belső pénz zsugorodását ellensúlyozza. Kelton erre javasolja megoldásként a költségvetési korlát mellözését.

\section{b) A költségvetési kiadás valódi korlátja az inflációra gyakorolt hatás}

A második fejezet azt a mitoszt rombolja le, hogy a deficit mindig mértéktelen és indokolatlan költekezést jelentene. Kelton szerint a deficit vállalása a mai helyzetben indokolt, és az erőforrások hatékony kihasználásához, mindenekelőtt a foglalkoztatás fenntartásához nélkülözhetetlenül szükséges. A deficit mértéke csak akkor lenne túlzott, ha a gazdaság növekedése eröforráskorlátokba ütközne, és emiatt a deficit inflációt gerjesztene. A későbbiekben még visszatérek arra a kérdésre, hogy a deficitnek ebben a felfogásban nincs finanszírozási, de van reálgazdasági korlátja. Ebben a fejezetben Kelton ezek közül csak az inflációt említi, és ennek kiemelt jelentőséget 
tulajdonít. De ehhez érdemes megemlíteni és hozzátenni több más mutatót, amelyek összességében olyan reálgazdasági korlátot jeleznek, ami az erőforrás-kihasználás feszültségeire utalhat. Ilyen az árfolyam, a kapacitások kihasználtsága, a munkanélküliség és a kereskedelmi mérleg egyenlege. Ez a felsorolás nem teljes, de talán érzékelteti, hogy bár elfogadhatjuk Kelton szándékát a költségvetési deficit adott esetben indokoltnak és szükségesnek tekinthető vállalásával kapcsolatban, mégis jogos ellenérzést kelthet ennek egyoldalú beállítása. A korlátok inflációra való leegyszerüsítése olyan aktualizáló törekvés, ami a jelen körülmények között kétségkívül hangzatos állítás megfogalmazását jelenti, mítoszként beállítva a deficittel szemben felhozható érveket. Ezek között számos felvetés valóban mítosz, ugyanakkor Kelton leegyszerüsítő megközelítése, bár kétségtelenül hatásos megfogalmazás, utat nyit olyan egyoldalú értelmezéseknek, amelyek feleslegesen váltanak ki ellenkezést a kétkedők körében. Így valójában nem növelik, hanem csökkentik a fő érv meggyőző erejét.

c) A költségvetési deficit nem terheli a jövö generációit

A könyv harmadik fejezete azt a mítoszt cáfolja, hogy a mai deficit a jövő generációit terheli majd. Legfontosabb megállapítása az, hogy amennyiben a költségvetés mai kiadása hozzájárul a vagyon növekedéséhez, addig nem szegényíti, hanem gazdagítja a jövő generációt. Ez is attól függ tehát, hogy a költségvetési pénzek felhasználása mennyire észszerủ és indokolt.

d) A deficitfinanszírozás nem szorítja ki a magánszektort

A negyedik mítosz az, hogy a költségvetési deficit kiszoritja a vállalatokat a beruházások finanszírozásából és a növekedésből. A könyv negyedik fejezetében Kelton azt mutatja be, hogy éppen ellenkezőleg, a költségvetés költekezése útján stimulált gazdaság új növekedési lehetőségeket nyit a magánvállalatok számára (Kelton, 2020a:96).

A költségvetési kiadás ugyanis a magánszektor számára bevétel. Számviteli azonosság, hogy amennyiben a költségvetés deficites, akkor a magánszektornak (más jövedelemtulajdonosnak) többlete kell, hogy legyen. A pénzáramlások Godley táblázataiban ábrázolt összefüggéseit összevontan mutatja be Keen (2020), aki a gazdaságot három szektorra bontva elemzi. A három szektor a következő: a központi bank és a költségvetés összevont kormányzati szektora, a bankszektor és a magánszektor (lakosság és a vállalatok összevontan). Emellett külön megjeleníti a magánszektor 
és a bankszektor összevont mérlegét, amit nem kormányzati szektornak, valamint a kormányzati szektor és a magánszektor összevont mérlegét, amit nem bankszektornak nevez. Az összevont ábrázolásban világosan látszik, hogy a kormányzati szektor deficitje csak úgy jöhet létre, ha a nem kormányzati szektornak azonos mértékủ többlete van. A hagyományos érvelés sem kételkedik a számviteli azonosságokban, de úgy tartja, hogy a költségvetési deficit a külföld számára jelent többletet, vagyis fizetésimérleg-deficittel jár (ikerdeficit). Ez az érv persze nem más, mint amit korábban már érintettünk. Ha a költségvetés a belföldi foglalkoztatást élénkíti, akkor a keresletet nagyobb valószínűséggel belföldi kínálatból fogják kielégíteni, és ez nem okoz automatikusan importtöbbletet. Vagyis a költségvetési programok észszerüsége vagy annak hiánya befolyásolhatja, hogy a többletkereslet belföldi keresletre vagy importra irányul-e.

e) A külkereskedelmi deficit nem függöséget, hanem fogyasztási többletet jelent

Az ötödik fejezet foglalkozik a külkereskedelem egyenlegével. Eddig az érvelés zárt gazdaságra vonatkozott. Az USA kereskedelmi deficitje sokakat nyugtalanit, de Kelton szerint ezt úgy kell értelmezni, hogy az amerikaiak árutöbbletet élvezhetnek, többet fogyaszthatnak, mint amennyit megtermelnek. Ennek ára az, hogy dollárral fizetnek a többletfogyasztásért is, mint ahogy azt teszik általában a boltban. A dollár előállítása azonban sokkal kevesebbe kerül, mint az érte megszerzett áruk elóállítása. Különösen igaz ez, ha számlaelszámolásokról van szó, mint általában, amikor nem is kell kinyomtatni és szállítani a fizetséget, pusztán jóváírják azt a bankok elektronikusan a számlákon. Nevetségessé tett mítoszként megfogalmazva ez az érv is meggyözö.

f) A szociális és infrastrukturális kiadások nem jelentenek fenntarthatatlan finanszirozást

A hatodik fejezetben Kelton levonja a következtetést abból, hogy az USA költségvetésikiadás-növelése nem fenyeget államcsőddel. Ha ugyanis az állami pénzteremtésnek csak az infláció állíthat korlátot, akkor a jelenlegi globális gazdasági tendenciák alapján nyugodtan mondhatjuk, hogy a társadalombiztosításra és az egészségügyre fordított állami kiadások sem fenyegetnek ezzel. Vagyis téves mitosz az az állitás, hogy az ezekre forditott összegek növelése költségvetésiadósság-válsággal fenyegetne. A szociális kiadások növekedése azonban kisebb eséllyel járulna 
hozzá a gazdaság erőforrásainak kihasználásához, így növekedési vagy foglalkoztatási hatása és ezen keresztül a jövőbeli költségvetési bevételek növeléséhez való hozzájárulása alacsony lehet. Emiatt az ilyen javaslatok ellenzői az adónövelési hatástól tartanak. Kelton ezt az adónövelést a közszolgáltatások foglalkoztatást növelő hatásával indokolja.

A hetedik és nyolcadik fejezet tovább folytatja a hatodik gondolatmenetét, és az oktatási és az infrastrukturális kiadások növelése mellett száll síkra, valamint hangsúlyozza, hogy amíg a költségvetési hiány növelése nem okoz inflációt, a klímaváltozás kihívásaira való felkészülésre, a gazdaság zöldítésére irányuló állami szerepvállalás elodázása hibás politika. A gazdasági konjunktúra befolyásolására és a társadalmi igazságosság érdekében a legfontosabb mégis a munkalehetőségek biztosítása (job guarantee). Ez azt jelenti, hogy az állam recesszió idején elsősorban a közszolgáltatások és az ellátás területén foglalkoztatási lehetőségeket biztosítva ellensúlyozná a visszaesés következményeit, és azután vonulna ki ebböl időlegesen, hogy a gazdasági növekedés helyreállt. Meg kell itt jegyezni, hogy az MMT ezt a megközelítést tartja célszerünek, szemben más, az alapjövedelemhez hasonló javaslatokkal. Az alapjövedelem kapcsán az MMT azt vallja, hogy a mai bonyolult és egyenlőtlen társadalmi juttatás összevonását és egyszerübb, ugyanakkor igazságosabb kezelését tenné lehetővé az alapjövedelem bevezetése, de ezt nem ruházná fel konjunktúraszabályozó funkciókkal.

\section{Kételyek, válaszra váró kérdések}

Nos, Kelton könyvének a deficittel kapcsolatos mítoszrombolása kapcsán a kételkedőkben, akik a hagyományos makroökonómiát tanulták meg jól, számos kérdés felmerül, aminek hangot is adnak. Ezek közül talán a legfontosabb, hogy vajon minden kormány bátran költekezhet-e, remélve, hogy az általa teremtett pénzzel ez finanszírozható? Erre Kelton (és az MMT) válasza az, hogy nem, ugyanis csak azon országok esetében igaz ez, amelyek az adósságuk finanszírozásában szuverének, vagyis amelyeknek a pénzét mindenki elfogadja. Mihelyt ebben nehézség adódna, az adósság növekedése is falba ütközne, és tovább már nem lenne érvényes a fent kimondott tétel, miszerint a deficit valójában szabadon használható árutöbbletet jelent, amitől nem kell félni, inkább örülni lehet neki. A deficit adósságot növel, ami után kamatot kell fizetni. De a kamatot is dollárban fizetik, tehát ez sem kell, hogy visszatartson bárkit Amerikában a külföldi termékek fogyasztásától. Mely országok élvezik ezt a kiváltságot? A közvélekedés szerint ilyen ország az USA, Ausztrália, 
Japán és az Egyesült Királyság, és még sok más ország (Kelton, 2020a:19). Érdekes módon Kanada is ide sorolható, sőt talán még inkább, mint az USA, bár nem a kanadai dollár nemzetközi pozíciói miatt, hanem a pénzügyi rendszer és a jegybank likviditáskezelési gyakorlata okán. Kanadában a klíringrendszer napi működési gyakorlata közel áll az MMT által feltételezett jellemzőkhöz (Lavoie, 2010, 2019). Ezt a kiváltságot viszont könnyủ elveszíteni. Mihelyt a kormány olyan gazdaságpolitikát folytat, amely kételyeket támaszt a pénzével kapcsolatban, máris megrendülhet a bizalom, ami e kiváltság alapja. Tehát gondolhatjuk, hogy bizonyos mértékben szinte bármely ország élhet ezzel a kiváltsággal, mindez csak mérték kérdése. Mindaddig, amíg saját szuverén kibocsátású valutájában adósodik el az ország, ennek az eladósodásnak nincsen csődkockázata, mert saját valutában az adósságszolgálatnak sincsen gyakorlati akadálya. Igazából azonban ez sem garancia, mert a saját valutában történő eladósodás is jelenthet külföldiek kezében lévő adósságot, és az ő bizalmuk könnyen elveszíthető, vagyis adott esetben a spekulatív ügyleteiket gyorsan fel tudják számolni.

Ha már itt tartunk, ebből a szempontból a belföldiek kezében felhalmozódott adósság sem sokban különbözik, mert a belföldi befektetők bizalmát is meg kell szolgálni. Kelton erre azt mondja, hogy ha a magánszektor szabadulni akar az államkötvénytől, akkor a jegybank akár az egész államadósságot felvásárolhatja. Ekkor nem történik más, mint az adós helyén az állam helyett a jegybank jelenik meg számlatulajdonosként, az állampapíroktól szabaduló magánszektornál pedig megjelenik a pénz. Vagyis a forgalomban lévő pénz mennyisége ennyivel növekszik. Ez az eredmény úgy is létrejöhet, hogy az állami deficit (adósságnövekedés) révén teremtett külső pénz úgy kerül a forgalomba, hogy például a jegybank vásárolja meg az állampapírokat közvetlenül az államtól a jegybank által nyomtatott pénzért, vagy az állam folyószámláján (költségvetési egyszámla) történő jóváírással. Ezt a pénzt a költségvetés a kiadásai során elkölti, és a pénz akkor kerül a forgalomba, amikor a magánszektor valamelyik szereplőjének számlájára kerül, és ő azt felhasználja.

Kelton e kijelentése arról, hogy a jegybank vásárolja fel az összes állampapírt, kétségtelenül megdöbbentő. Megdöbbentő, mert valóban igaz, ha a jegybankot az állam részeként nézve a tranzakciók végeredményét tekintjük csak, vagyis abban az esetben, ha a jegybank és a költségvetés számláit összevontan kezeljük. De sokan joggal azért is megütközhetnek ezen az állításon, mert a mai modern gazdaságokban ez több áttételen keresztül megvalósuló folyamatot érint, és az e lépéseket szabályozó számviteli elszámolási elvek és költségvetési szabályok kifejezetten tiltják azt, hogy a jegybank közvetlenül (egy lépésben, ahogy az MMT összevontan nézi 
ezt) az államot finanszírozza, vagyis az összevont kezeléssel adódott kép mögött feltételezett finanszírozási lépés a valóságban kizárt. Kelton kijelentése olyan értelmezést sugall, amelyhez meg kellene változtatni a gyakorlatot meghatározó elveket és szabályokat.

Ha a jegybank a nála lévő államkötvényeket eladja a magánszektor valamelyik szereplöjének, akkor a korábban teremtett pénzt kivonja a forgalomból, de a kötvény új tulajdonosa a magánszektorban bármikor eladhatja papírjait, hogy adott esetben pénzéhez juthasson és vásároljon, vagy számláján azt jóváírassa. Kelton összevont értelmezése szerint ez a tranzakció portfólióátrendezés, a magánszektor készpénz (betét) és kötvény aránya változik, de ettől önmagában nem változnak a vásárlási szokások, vagyis ennek nincsen inflációs hatása. Ezt az állítását sokan hasonlóképpen hitetlenkedve fogadják, és ezek között az MMT-vel szimpatizálók közül is sokan a korlátokat hangsúlyozzák. A költségvetési deficit nyomán teremtett külső pénz mennyiségének mindaddig nincs korlátja, amíg az államadósság növekedése nem jár a gazdaság egyensúlyának felborulásával, amit például az infláció elszabadulása jelez. Igazában Kelton maga is így gondolja (lásd a második mítosz kapcsán: „,a költségvetési költekezés addig nem túlzott, amíg nem okoz inflációt”).

A legfontosabb kommunikációs üzenetek (a mítoszok megkérdőjelezése) közérthető megfogalmazása érdekében a szakmai részletek konzekvens feltárásával, az aprómunka elvégzésével a szerző számos esetben adós maradt. Kelton nagyvonalúan és leegyszerüsítve kezeli például a költségvetés, a jegybank és a magánszektor finanszírozási kapcsolatait. Kijelentései akkor tekinthetők megalapozottnak és igaznak, ha a jegybankot és a költségvetést összevontan vesszük, vagyis ahogy korábban említettük, a jegybankot az állam részének tekintjük, és a költségvetés és a jegybank mérlegét összevonjuk. Ez azt jelentené, hogy a jegybank lényegében a költségvetés része, amely a finanszírozást bonyolítja. Ilyen jegybank azonban a modern világban nem létezik, sőt a politikai kockázatok miatt egyenesen tiltott, hogy a jegybank közvetlenül finanszírozza a költségvetést. A költségvetés újonnan kibocsátott kötvényeit tehát nem automatikusan a jegybank vásárolja meg, hanem a magánszektor. A jegybanknak természetesen van lehetősége a pénzügyi szabályozáson keresztül befolyásolni a magánszektor befektetési döntéseit, de ez nem direkt beavatkozást jelent. A jegybank ugyanakkor szabadon vásárolhatja a magánszektortól az állampapírokat, és ha a jegybankot és a költségvetést egy összevont mérlegben írjuk fel, akkor több tranzakciós lépést összevonva ez úgy tünik, mintha a költségvetéstől venné azokat. Csak az is fontos, hogy ez nem egy lépésben történik a valóságban, hanem 
legalább kettőben. ${ }^{7}$ Ha összevontan vesszük, akkor Kelton meglepö kijelentései igazak, de a valóságban ehhez hozzá kell tenni, hogy az általa lerövidített és összevont tranzakciós mechanizmus a valóságban nem így müködik. Gazdaságpolitikai javaslatait, legyenek azok bármennyire meggyőzőek vagy meglepőek, csak akkor lehet a gyakorlatban alkalmazni, ha a gazdaság müködési mechanizmusait meghatározó szabályrendszert és elszámolási kereteket erre alkalmassá tesszük.

Ha azt gondoljuk, hogy majdnem minden ország élhet a finanszírozás szempontjából korlátlan deficit kiváltságával, csak mérték kérdése a dolog, akkor az is felmerülhet, hogy az USA vagy a másik néhány kiváltságos ország, amely bátran és szinte korlátlanul élhetne ezzel, elveszítheti-e ezt a kiváltságot. A válasz az, hogy igen, és ezt Kelton is elismeri. A nemzetközi pénzpiacok számára hiteltelen gazdaságpolitika az USA esetében is ilyen következményekkel járhat.

\section{Összefoglalás}

Kelton könyve kettős szemléletváltást hozott a költségvetési deficit és a gazdaságpolitika összefüggésében. Elöször is meggyőzően bizonyította, hogy a költségvetési eszközökkel hatékonyabban lehet a gazdasági ingadozásokat befolyásolni, mint a monetáris politikával. A monetáris politika nem alkalmas a konjunkturális ciklusok kezelésére. A másik szemléletformáló hozzájárulása a gazdaságpolitikai vitákhoz az, hogy bemutatja: a gazdaságpolitika költségvetést érintő intézkedései közötti választás nem közgazdasági, hanem politikai kérdés. A politikai preferenciák határozzák meg, hogy mire és mennyit költ az állam. Ebben a konzervatív és a liberális, a jobb- vagy a baloldali megközelítés közgazdaságilag egyaránt indokolható vagy kifogásolható (Kelton, 2020:235). Despain (2020) ezzel kapcsolatban jegyzi meg, hogy bárki tökéletesen egyetérthet Kelton közgazdasági érvelésével, még akkor is, ha egyetlen gazdaságpolitikai javaslatát sem tartaná elfogadhatónak.

Kelton könyve minden egyoldalúsága ellenére nagyon fontos változást hozott azzal, hogy bebizonyította: a költségvetési kiadásokat érintő politikai diskurzus-

\footnotetext{
7 A klíringmechanizmus múködését mérlegösszefüggéseken keresztül mutatja be Lavoie (2013), és alaposan elemzi a döntő elvi eltéréseket a között, hogy a jegybank egy vagy több lépésben vesz-e részt a költségvetési kötvények kibocsátásán keresztül végbemenő pénzteremtésben. E megközelítés világosan bizonyítja, hogy bár a végeredmény a mérlegek összevonása után ugyanaz, mégis teljesen más gazdasági működés áll a háttérben. Ezzel szemlélteti, hogy a Kelton által képviselt leegyszerüsítő kép a végeredményt tekintve összerakható, a valóságban jelenleg megtalálható gazdaságok pénzügyi (klíring-) rendszere azonban nem így múködik. A hangzatos kijelentések így a valóságos gazdaságokra nehezen húzhatók rá.
} 
ban a héja vagy galamb megkülönböztetésnek nincsen értelme. Meggyőzően alátámasztotta, hogy az állami kiadásoknak költségvetési finanszírozási korlátja nincsen, ehelyett reálgazdasági korlátok vannak, és ha ezeket a korlátokat figyelmen kívül hagyják, akkor a gazdaság müködésében zavarok keletkeznek, ami inflációhoz vezet. Kelton fontos eredménye az is, hogy a költségvetés kapcsán nem a hiány nagyságával kellene érvelni és azt misztifikálni, hanem azt kell világosan mérlegelni, hogy milyen kiadási programokat finanszírozzunk.

Ábel István

\section{Hivatkozások}

Ábel I. (2019). Pénz és kamat. Prosperitas Monográfiák, Budapest: Budapesti Gazdasági Egyetem. https://uni-bge.hu/Kutatasi-tevekenyseg/Folyoiratok_kiadvanyok/Prosperitas-folyoirat/ Monografia/dokumentumok/Abel_Istvan_Penz_es_Kamat.pdf

Ábel I., Lehmann K. \& Tapaszti A. (2016). A pénz és a bankok ellentmondásos kezelése a makroökonómiában. Hitelintézeti Szemle / Financial and Economic Review, 15(2), 33-58. https:// hitelintezetiszemle.mnb.hu/letoltes/abel-istvan-lehmann-kristof-tapaszti-attila.pdf

Ábel, I. \& Lehmann, K. (2019). Real and Monetary Theories of the Interest Rate. International Journal of Political Economy, 48(4), 353-363.

Ábel I., Lóga M., Nagy Gy. \& Vadkerti Á. (2019). Rántsuk le a fátylat a kamatról! Hitelintézeti Szemle/ Financial and Economic Review, 18(3), 29-51. https://hitelintezetiszemle.mnb.hu/letoltes/hsz-183-t2-abel-loga-nagy-vadkerti.pdf

Cochrane, J. H. (2020). 'The Deficit Myth' Review: Years of Magical Thinking. At least Bernie Sanders believes spending depends on tax revenue. Modern monetary theory says: Dream big! Wall Street Journal, June 5. https://www.wsj.com/articles/the-deficit-myth-review-years-of-magicalthinking-11591396579

Despain, H. G. (2020). Book Review: The Deficit Myth: Modern Monetary Theory and the Birth of the People's Economy by Stephanie Kelton, London School of Economics Review of Books, June 22. https://blogs.lse.ac.uk/lsereviewofbooks/2020/06/22/book-review-the-deficit-myth-modernmonetary-theory-and-the-birth-of-the-peoples-economy-by-stephanie-kelton/

Fiebiger, Brett \& Lavoie, M. (2020). Central bankers and the rationale for unconventional monetary policies: reasserting, renouncing or recasting monetarism? Cambridge Journal of Economics 2020, beaa035, https://doi.org/10.1093/cje/beaa035

Jackson, G. (2020). The Deficit Myth by Stephanie Kelton. A leading light of modern monetary theory illuminates the debate. The Financial Times, July 5, 2020. https://www.ft.com/content/673b0be23559-4b61-9224-7c271ae4ed31

Ábel István, egyetemi tanár, Budapesti Gazdasági Egyetem. E-mail: abel.istvan@uni-bge.hu

Dr. Nagy Gyulának (Budapesti Gazdasági Egyetem) és Szalai Zoltánnak (MNB) köszönöm az anyag összeállításához nyújtott segítségüket.

A tanulmány az MTA-BGE Makrogazdasági fenntarthatósági kutatócsoport keretében, a Támogatott Kutatócsoportok Irodájának támogatásával készült.

A kézirat első változata 2020. augusztus 30-án érkezett szerkesztőségünkbe.

https://doi.org/10.47630/KULG.2020.64.9-10.90 
Keen, S. (2020). A Mathematical Model of Modern Monetary Operations. Posted on August 25, http:// econintersect.com/pages/analysis/analysis.php?post=202008250059

Kelton, S. (2020a). The Deficit Myth: Modern Monetary Theory and the Birth of the People's Economy, Public Affairs, New York.

Kelton, S. (2020b). Learn To Love Trillion-Dollar Deficits. Our country's myth about federal debt, explained. The New York Times, June 9. https://www.nytimes.com/2020/06/09/opinion/us-deficitcoronavirus.html

Keynes, J. M. (1965). A foglalkoztatás, a kamat és a pénz általános elmélete. Budapest: Közgazdasági és Jogi Könyvkiadó.

Lavoie, M. (2010). Changes in central bank procedures during the subprime crisis and their repercussions on monetary theory. International Journal of Political Economy, 39(3), 3-23.

Lavoie, M. (2013). The Monetary and Fiscal Nexus of Neo-Chartalism: A Friendly Critique, Journal of Economic Issues, 47(1), 1-32., DOI: 10.2753/JEI0021-362447010

Lavoie, M. (2019). A System with Zero Reserves and with Clearing Outside of the Central Bank: The Canadian Case, Review of Political Economy, 31(2), 145-158. DOI:10.1080/09538259.2019.16169 22

Murphy, R. P. (2020). Review of Stephanie Kelton, The Deficit Myth: Modern Monetary Theory and the Birth of the People's Economy, Mises Wire, June 23. https://mises.org/wire/review-stephaniekeltons-deficit-myth

Pogátsa Z. (2020). A költségvetési deficit mítosz, Új Egyenlöség, június 14., https://ujegyenloseg.hu/akoltsegvetesi-deficit-mitosz/.

The Economist (2020). The Covid-19 pandemic is forcing a rethink in macroeconomics, July 25. https://www.economist.com/briefing/2020/07/25/the-covid-19-pandemic-is-forcing-a-rethink-inmacroeconomics

\section{Köszönetnyilvánítás}

A jogszabály adta lehetőségekkel élve sokan utalták át 2019. évi személyi jövedelemadójuk 1 százalékát a Kopint Konjunktúra Kutatási Alapítvány javára.

\section{A kapott összeg 40875 forint.}

Köszönetet mondunk mindazoknak, akik Alapítványunkat támogatásra érdemesítették. 